\section{MANO BLANCA Y OTROS POEMAS}

WHITE HAND AND OTHER POEMS
Textos del libro

MANOBLANCA Y OTROS POEMAS

De Ciudad que palpita

El Lirio y el Espanto

Hay un olor a estiércol y amapola en el ambiente.

Los maniquíes vestidos de novia

se frotan contra los escaparates

Como si algo buscaran los obreros

continúan levantando la costra de las calles

Alguien dijo que este día sería

Frágil como la muerte

Por la ventana pasan sólo las sombras

de pajaros que nunca imaginaremos.

II

\section{Enrojecen los semáforos.}

Un niño pasa corriendo

con un remolino entre las manos

Hay máscaras colgando del tendido eléctrico

Yo he visto humedecerse los ojos de la calle

En el hospital hay sábanas azules

flameando hacia la muerte

Una cama vacía

se despierta reclamando cuerpos.

Se empañan por dentro las vitrinas.

Un esqueleto pasa conduciendo un automóvil

Nos queda apenas

el grito de un lirio cortado en el bolsillo

el camillo

Elcinior

triciclos oxidados dentaduras postizas

Alguien me quiebra brazos y piernas

Enrojecen los semáforos.

IV

Un vago permanece incrustado en la vereda

barajando entre sus dedos los rostros que pasan

Yo lo mantengo enhebrado a mi retina

como un pez silencioso y terrestre

Estoy viendo humedecerse los ojos de la calle

mientras las palas mecánicas se acercan

Hay un olor a estiércol y amapola en el ambiente.

Paisaje con Mujer en Medio

La lluvia deposita

sus puntos suspensivos sobre el cemento.

A manos de parejas y delincuentes habituales

empiezan a florecer los paraguas.

La sombra de un árbol en la otra orilla

cruza el río temblorosa

hasta rozarme los zapatos.

El cráneo de la luna nos observa incrédulo.

Las campanas de la tarde

mascan los últimos latidos de la anciana ebria

que se deja diluir lentamente bajo el puente. 
Los niños envejecen de golpe.

La Llave

Para poder llorar los hijos

toman prestado el rostro de la abuela muerta.

Dios sigue siendo una piedra que se llena

de musgo en el jardín de al lado.

Con la memoria en llamas

en medio de una lucidez terrible

tiemblo me empapo

sigo encontrando trozos de espejo en las veredas.

Alguien dijo que este día sería

frágil como la muerte.

Un candado habita en la puerta de la iglesia.

Con un beso ciego atravieso el silencio

y me hundo en la pupila de esta noche inabarcable.

Como un Trapecista Sobre un Trazo de Luz

La ciudad te escribe preguntas en las esquinas.

Se abre la noche y florecen signos

de interrogación en los semáforos.

Deambulas por la calle

buscando una boca precisa que te nombre

depositando pasos en la línea blanca

como un trapecista sobre un trazo de luz.

Atraviesas la noche

recuerdas que el poema alguna vez fue un puente

tendido entre tu abismo

y el abismo de otros

el viento lamía los cuerpos

te esperaba luego entre las sábanas de la página.

Ahora

extraviada la pértiga

avanzas con cautela sobre la línea blanca.

Los pasos que describes son puntos suspensivos

a punto de caer rodando hacia el silencio.

De Fragmentos de Invierno

Estoy incendiando mi cabellera

salgo a correr desnuda bajo la lluvia

y voy abriendo los cercos podridos por el otoño.

Sobre mi cabeza se estrellan

panales de agua

un relámpago triza el pizarrón del cielo

los perros insultan al viento

y el viento huye

a esconderse en las alcantarillas.

Debiera yo pedirte

perdón por este invierno.

Mi boca se llena de pájaros ciegos.

Soy un pañuelo dormido bajo la lluvia.

No sé dónde iré a encallar

cuando la noche quede en ruinas.

Hallazgo

a ciudad se concentra en la esquina donde te encuentro

La ciudad que palpita

y ya no vuelve a ser la misma

bajo tus zapatos.

Porque todos los años que he vivido

me condujes los añ

me visto de fiesta

me visto de fiesta

es decir me desvisto

y el sol como una manzana roja

cae sobre un horizonte hambriento.

( La madrugada nos sorprende

envenenados

con un gajo de cielo entre los dientes

De En las Copas de Onyris

Vértigo

Habita la Muerte

entre los dedos del fuego

bailarina cálida

crepitando su canción de cuna.

En el ojo vertical de una llama

instala ella su pupila

azul y nos concede una tregua.

Por eso nos quedamos

inmóviles ante el fuego.

Como un embrión que abre

los ojos en el vientre

como un gato desconcertado

ante el espejo

un sol cegado por sí mismo

a mediodía

un niño ebrio

que contempla a sus abuelos

apareándose en un acuario.

El Espejo

Quitarse la cáscara del día

las luces de colores

las ropas que a veces duelen

despojarse de la risa

Abrir la carne y encontra

el cuesco de la tristeza

uelve reales.

Entrar en cuadrante del espejo

hundirse en ese otro cielo

desarraigado de preguntas

levantar la mirada y encontrar

el ojo vertical que nos observa

atravesando la frente.

$Y$ atravesar la frente.

Separarnos en gajos

abrir los ángulos gastados de la memoria

trazar la cruda desnudez la necesaria

cobijar el pez verde que nos navega.

Desarmarnos Desglosarnos 
volver a lo que fuimos antes de

tener un nombre

y de tanto desbordarnos

en el agua crucial del espejo

reconstruirnos sin aditamentos

con la honestidad de una gota de lluvia

en la ventana del silencio.

Textos del libro

MIGRACIONES

In Situ

De regreso a la casa de las flores de plástico

y cristos colgando de la pared

El polvo duerme el sueño de los justos

y me someten a interrogatorio los muebles.

Ni una sola huella de mí.

Ya no ejerzo la boca ni cuerpo tengo

Aquí Yo Ahora

estirándome como lombriz en la vered

lanzando mis caracolas al vacío

Aquí Yo Ahora

desnuda de ti

suspendida en el acto de desamar

Aquí Yo Ahora

escupiendo palabras rojas en el lavamanos

que se escurren sin vuelta atrás.

In Actio

Escapo hacia el borde de la cama

a punto quedo de salirme de la página

colgando de la cornisa

como nieve herida por el sol.

Sueño que mi cuerpo es mordido por cantaurias

llego al pie de un árbol poblado de peces

que nadan en el aire lento del verano

mordisqueando frutas y pezones.

Entre sábanas interminables

masturbo este cuerpo salvajemente

y luego el lento proceso de tu

c a re n cia

la ceniza espeluznante de la ira

ésforos que se curvan crepitando

con las cabezas adheridas y en llamas.

Lluevo

Se me trizan las palabras contra las

paredes del cráneo

luevo

作

os dientes

lluevo

me crepita un archipiélago de tripas

lluevo

abro los poros uno a uno

abro los poros uno a uno

lluevo zapateo sobre los tejados

vestida de mortaja y viento

lluevo

me incendio gota a gota

sílaba a sílaba

lágrima a beso.

Lluevo

Lluevo

luevo

Y la sordera del tiempo.

Corolario

Hay que volver a la caligrafía

Regresar al curso del papel

Prescindir del filtro y el teclado

Limpiar la voz de las retóricas

Y la piel de los vestuarios

El ojo del lente

Liberar al hombre de sus nombre

Desmenuzar los restos aún tibios del sol

Hasta encontrar la primera gota

De la noche que olvidamos. 